\title{
Pengembangan E-Modul Fisika Berbasis STEM (Science, Technology, Engineering, and Mathematics) Pada Materi Bunyi di SMA/MA
}

\author{
Dewi Syarah Syahiddah ${ }^{1 *}$, Pramudya Dwi A.P ${ }^{2}$, Bambang Supriadi ${ }^{3}$ \\ 1,2,3 Pendidikan Fisika, Fakultas Keguruan dan IImu Pendidikan \\ Universitas Jember (UNEJ), Jawa Timur - Indonesia \\ ${ }^{\star}$ E-mail Penulis Korespondensi: dewisyarahsyahiddah@gmail.com
}

\begin{abstract}
Abstrak
Penelitian ini bertujuan untuk mendeskripsikan validitas E-Modul Fisika berbasis Science, Technology, Engineering, and Mathematics (STEM) pada materi bunyi di SMA/MA. Metode penelitian yang digunakan yaitu R\&D dengan menggunakan model ADDIE (Analysis, Design, Development, Implementation, and Evaluation). EModul fisika berbasis STEM dibuat menggunakan aplikasi anyflip dan dapat diakses melalui smartphone (android maupun ios) serta PC/Mac melalui link yang telah disebarkan oleh guru mata pelajaran fisika. Berdasarkan hasil validasi dari validator ahli dan pengguna, E-Modul fisika berbasis STEM layak untuk digunakan dalam proses pembelajaran. E-Modul fisika berbasis STEM ini merupakan bahan ajar yang menjadi alternatif bagi guru dan siswa selama proses pembelajaran di era pandemi ini. E-Modul ini dapat mempermudah siswa dalam memecahkan permasalahan yang ada dalam kehidupan sehari-hari, karena modul ini terintegrasi dengan empat bidang STEM. E-Modul ini dilengkapi dengan ilustrasi, animasi, dan latihan soal yang juga terdapat penilaian mandiri untuk mengukur keberhasilan siswa dalam kegiatan belajar yang terdapat dalam E-Modul.
\end{abstract}

Kata kunci: Bunyi, E-Modul, STEM.

\section{Abstract}

This study aims to describe the validity of physical E-Module based science, technology, engineering, and mathematics in the concept of sound in senior high school. A Research method in this study is R\&D by using ADDIE model, (Analysis, Design, Development, Implementation, and Evaluation). Physical E-Module based on the STEM made by using anyflip application and it could be accessed via smartphone (android/IOS) and PC/Mac. This E-Module had been validated by experts and user which showed the results physical E-Module based on the STEM approaches is suitable for learning process. Physical E-Module based STEM is an alternative learning materials for teachers and students during the pandemic era. Physical E-Module can help the students to solve the problems in their daily lives this E-Module is integrated with four of science, technology,engineering, and mathematics. This E-Module equipped with illustration, animation, and exercises which was also found in selfassesment to measure level of succes in learning process.

Keywords: Sound, E-Module, STEM

Article History: Received: 19 Maret 2021 Accepted: 21 Maret 2021

\author{
Revised : 14 April 2021 \\ Published: 30 April 2021
}

How to cite: Syahiddah, D.S., Putra, P.D.A. \& Supriadi, B. (2021). Pengembangan E-Modul Fisika Berbasis STEM (Science, Technology, Engineering, and Mathematics) Pada Materi Bunyi di SMA/MA. Jurnal Literasi Pendidikan Fisika, 2(1). pp. 1-8. Retrieved from http://jurnal.fkip.unmul.ac.id/index.php/JLPF

Copyright (c) April 2021, Jurnal Literasi Pendidikan Fisika 
Pengembangan E-Modul Fisika...

\section{PENDAHULUAN}

Dunia pendidikan pada saat ini berkembang sangat pesat, seiring terjadinya perkembangan ilmu dan teknologi di seluruh dunia. Perkembangan dalam pembelajaran dapat dilihat dari beberapa hal diantaranya kurikulum, model pembelajaran, metode pembelajaran, bahan ajar yang digunakan dan lain sebagainya. Proses pembelajaran fisika akan lebih optimal jika pendidik menggunakan teknik penyampaian materi yang mencakup ceramah, diskusi, demonstrasi, evaluasi, dan eksperimen. Berdasarkan hasil observasi yang telah dilakukan di beberapa sekolah di salah satu di kabupaten di Jawa Timur ditemukan bahwa pembelajaran fisika seringkali diabaikan karena kurang menarik dan sulit dipahami oleh siswa. Hal ini disebabkan karena dalam pembelajaran fisika siswa hanya diarahkan pada konsep yang memiliki sifat abstrak sehingga sulit untuk direalisasikan dalam dunia nyata menurut Samudra dalam (Astiti, 2019).

Muhammad (2018), menyatakan bahwa salah satu faktor yang mempengaruhi kualitas pendidikan adalah kualitas tenaga pendidik dalam merancang dan melaksanakan pembelajaran. Pendidik diharapkan mampu untuk mendesain, mengembangkan, serta memanfaatkan media maupun bahan ajar sebagai salah satu bentuk upaya dalam meningkatkan motivasi, minat, dan perhatian peserta didik. Pada masa pandemi covid-19 ini banyak sekolah yang melakukan pembelajaran jarak jauh atau secara online. Permasalahan yang terjadi di masa pandemi covid-19 dalam dunia pendidikan di Indonesia ini adalah kurangnya minat siswa dalam melaksanakan proses pembelajaran (Herliandry et al., 2020). Berdasarkan hasil observasi beberapa tenaga pendidik di salah satu sekolah menengah atas menyatakan bahwa siswa cenderung bosan dengan proses pembelajaran jarak jauh karena banyaknya tugas dari setiap mata pelajaran yang membuat mereka merasa terbebani. Selain itu, kurangnya strategi pendidik dalam memanfaatkan teknologi serta media dan fasilitas penunjang pembelajaran lainnya menyebabkan siswa cenderung kurang tertarik dalam proses belajar mengajar. Selain dari siswa, pendidik juga kebingungan dalam hal menyusun strategi terbaik dalam menyesuaikan kondisi siswa maupun strategi dalam proses pembelajaran agar siswa dapat mencapai keberhasilan dalam materi yang diajarkan (Solviana, 2020). Penggunaan sumber belajar siswa dapat mempengaruhi hasil belajar. Bahan belajar siswa perlu disesuaikan dengan kondisi siswa dan strategi pembelajaran yang digunakan guru.

Mengingat kondisi sekarang bahwa dalam masa pandemi covid-19 berbeda dengan masa normal atau sebelumnya, siswa dan guru sama-sama mencari solusi untuk dapat melaksanakan pembelajaran secara efektif. Sehingga diperlukan suatu inovasi pembelajaran dalam menyusun sumber belajar yang dapat menjadi solusi dalam menunjang pembelajaran jarak jauh (Adam et al., 2020). Salah satu sumber belajar yang dapat menunjang peserta didik dalam belajar mandiri yaitu E-Modul. E-modul dilengkapi dengan petunjuk belajar mandiri, materi, contoh soal, evaluasi, dan pedoman penilaian yang dapat digunakan sebagai acuan ketercapaian kegiatan belajar yang dipelajari (Depdiknas, 2017).

Pengembangan dan inovasi di bidang pendidikan telah banyak berkembang hal ini terbukti dengan banyaknya aplikasi atau softwere baru dalam bentuk digital baik berupa animasi, simulasi maupun modul elektronik karena dapat memperluas ruang kelas melalui wawasan baru ke dalam realitas yang berbeda. Seiring dengan perkembangan teknologi tersebut, upaya yang bisa dilakaukan oleh pendidik terkait dengan keterampilan abad 21 untuk mengimbangi dunia pendidikan di era modern, salah satunya melalui STEM (Akaygun, 2016). Pembelajaran dalam pendekatan Science, technology, enginering and mathemtics dikenal sebagai pendekatan multi disiplin untuk pembelajaran, dimana konsep materi yang diajarkan akan disesuaikan kemudian digabungkan dengan kehidupan dalam dunia nyata. Menurut Burrows \& slater dalam (Shernoff et al., 2017). STEM diharapkan mampu mengurangi beban siswa untuk menghadapi permasalahan pada dunia nyata dengan menerapkan konsep yang menghubungkan berbagai ilmu pengetahuan. Penelitian lain menunjukkan pembelajaran STEM mampu membentuk minat (Latip, 2020) dan presepsi terhadap profesi yang terkait dengan STEM (Sulaeman et al., 2020). Walaupun pengembangan modul berbasis STEM banyak dilakukan

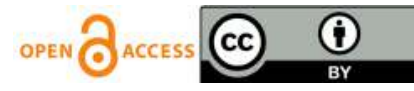


Pengembangan E-Modul Fisika...

(Hartini et al., 2020), namun pengembanagn E-modul dalam masa pandemi masih jarang ditemukan. Oleh karena itu, tujuan dari penelitian ini adalah untuk mengetahui validitas E-Modul fisika berbasis STEM pada materi bunyi di SMA/MA, untuk memudahkan dalam menganalisis validasi penelitian ini maka disusun rumusan masalah sebagai berikut "Bagaimana validitas E-Modul fisika berbasis STEM pada materi Bunyi di SMA/MA?".

\section{METODE}

Jenis penelitian ini merupakan penelitian pengembangan (Research and Development). Desain yang digunakan dalam penelitian ini menggunakan model ADDIE yang terdiri dari lima tahap pengembangan yaitu, Analysis, Design, Development, Implementation, and Evaluation. Berikut langkah-langkan penelitian dengan menggunakan model ADDIE: (1) Menganalisis masalah yang dihadapi oleh siswa dalam proses pembelajaran serta bahan ajar yang dibutuhkan dalam kegiatan belajar mengajar; (2) merancang tujuan pembelajaran yang akan digunakan sebagai acuan untuk merancang konsep produk yang akan dikembangkan; (3) mengumpulkan materi serta membuat produk yang sesuai dengan desain yang telah dibuat dan membuat instrumen penilaian serta divalidasikan sesuai dengan standar kelayakan E-Modul; (4) mengimplementasikan E-Modul sesuai dengan kondisi lapangan.

Tempat penelitian ditentukan dengan mengunakan metode purposive sampling area, yaitu berdasarkan tujuan dan beberapa pertimbangan salah satunya ketersediaan sekolah. Seluruh pihak yang ikut serta dalam proses penelitian ini didefinisikan sebagai subyek penelitian. Subyek dalam penelitian pengembangan E-Modul STEM dibagi menjadi dua kelompok sesuai dengan rumusan masalah yang telah dibuat yaitu ahli dan pengguna. Sebagai validasi ahli telah ditetapkan tiga orang sebagai ahli pembelajaran yang terdiri dari: satu ahli STEM, satu ahli keilmuan fisika. Sedangkan validasi pengguna telah dipilih satu ahli pengajar SMA di wilayah kabupaten Jember. Validasi ini dilakukan untuk mengetahui kelayakan produk yang dikembangkan.

Instrumen yang digunakan berupa angket berupa lembar observasi yang dikembangkan dengan menggunakan skala likert dengan ketentuan (1). Tidak valid sampai dengan (4). Sangat valid. Setelah mengisi nilai kevalidan, validator mengisi keterangan berupa saran dan kritik pada lembar yang telah disediakan. Akbar (2013), menyatakan bahwa teknik analisa data yang digunakan pada penelitian pengembangan ditunjukkan pada tabel 1 sedangkan untuk menentukan validasi E-Modul dianalisis menggunakan persamaan (1).

Presentase kevalidan $(\%)=\frac{\text { skor yang diperoleh }}{\text { skor maksimum }} \times 100 \%$

Tabel 1. Kriteria validasi E-Modul

\begin{tabular}{ccc}
\hline No. & Prosentase & Kriteria \\
\hline 1 & $x \geq 75 \%$ & Sangat Tinggi \\
\hline 2 & $50 \% \leq x<75 \%$ & Tinggi \\
\hline 3 & $25 \% \leq x<50 \%$ & Rendah \\
\hline 4 & $x<25 \%$ & Sangat Rendah \\
\hline
\end{tabular}

\section{HASIL DAN PEMBAHASAN}

\section{HASIL}

Hasil dari produk pengembangan dalam penelitian ini berupa E-Modul berbasis STEM pada materi Bunyi di SMA/MA. Pengembangan modul elektronik ini berpedoman pada kompetensi inti dan kompetensi dasar. E-Modul ini dibuat dengan menggunakan aplikasi berupa Anyflip yang dapat di akses secara online. Menu yang terdapat dalam E-Modul ini yaitu thumbnails, first page, previous page, zoom, last page, sosial share, Enable fullscreen, search, share mail, dan auto flip. Isi dari modul 
Pengembangan E-Modul Fisika...

elektronik ini yaitu cover, deskripsi, petunjuk penggunaan, kegiatan belajar, latihan soal, evaluasi diri, dan glosarium.

Cara penggunaan E-Modul ini yaitu dengan menggeser halaman ke sebelah kiri untuk melanjutkan ke halaman berikutnya atau ke sebelah kanan untuk mengembalikan ke halaman sebelumnya. Pada modul elektronik ini dilengkapi dengan barcode dan link youtube untuk tersambung ke animasi atau penjelasan tertentu pada beberapa sub materi yang berfungsi untuk memudahkan siswa dalam memahami materi tersebut. E-Modul berbasis STEM ini dapat diakses secara online melalui web https://anyflip.com/ynwue/kxia/ yang dibagikan secara langsung oleh peneliti baik kepada validator ataupun pengguna.

E-Modul berbasis STEM ini dapat diakses melalui smartphone dengan sistem android maupun ios dan dapat diakses melalui PC/Mac melalui link yang telah dibagikan oleh guru mata pelajaran. Langkah-langkah mengakses E-Modul berbasis STEM yaitu:

1. Buka Aplikasi Google yang terdapat pada smartphone atau PC (Gambar 1)

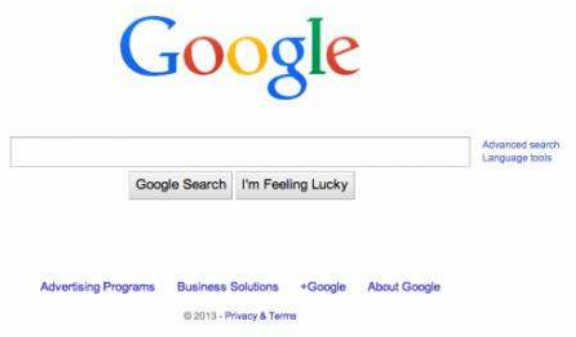

Gambar 1. Membuka Aplikasi

2. Salin link berikut ini https://anyflip.com/ynwue/kxia/

3. E-Modul sudah dapat di akses (Gambar 2)

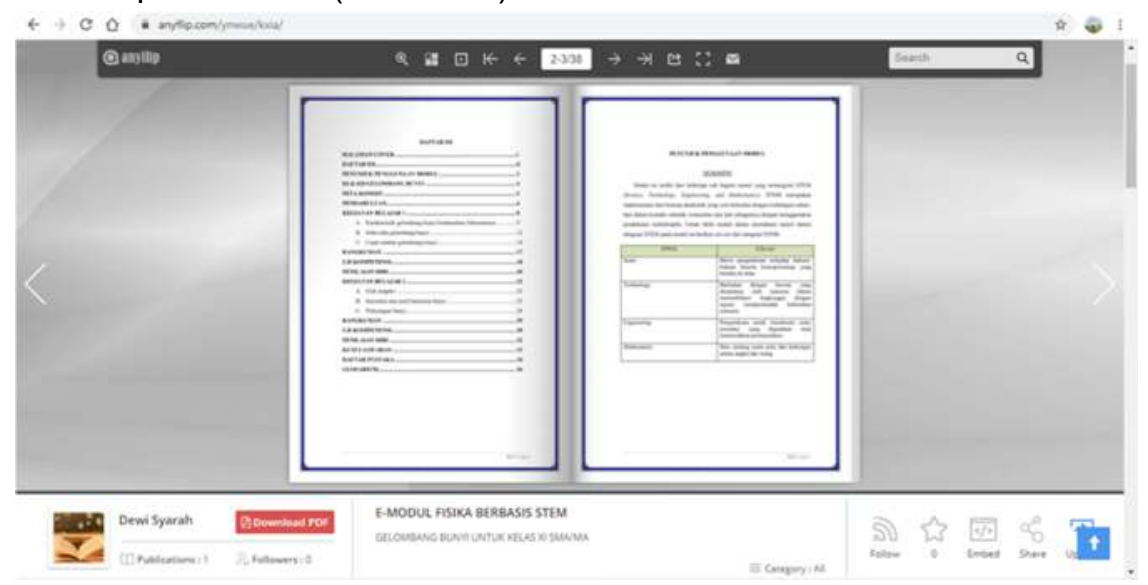

Gambar 2. Tampilan E-Modul

4. Jika ingin melihat keseluruhan isi E-Modul silahkan tekan thumbnail pada menu yang terdapat pada tampilan E-Modul (Gambar 3) 
Pengembangan E-Modul Fisika...

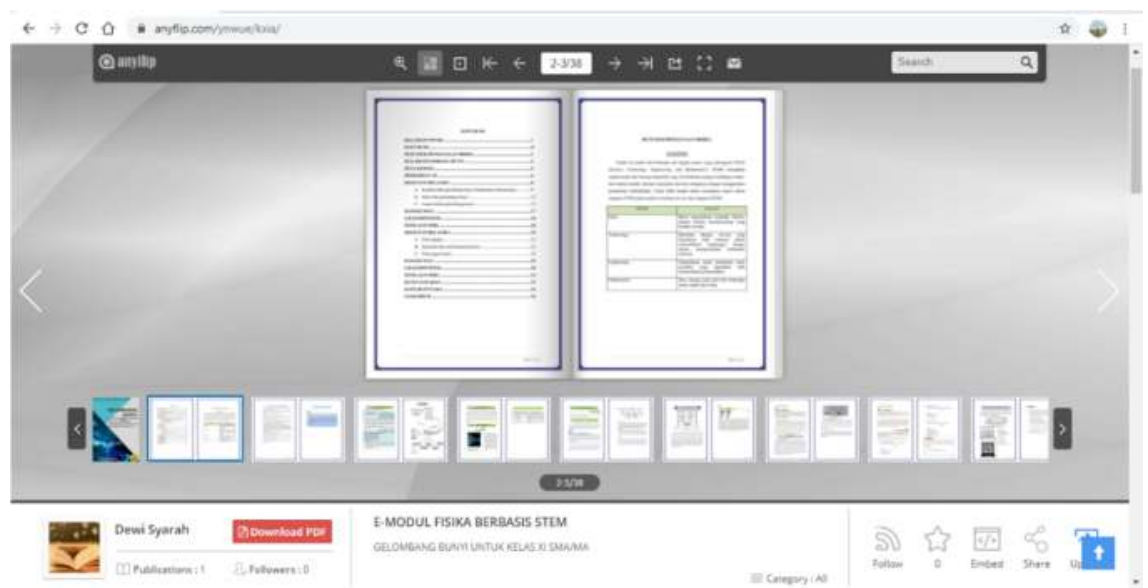

Gambar 3. Menu pada E-Modul

5. Jika ingin berlanjut ke halaman berikutnya silahkan geser layar pada smarthphone atau klik next page pada layar laptop

6. Jika ingin mencari salah satu topik dalam materi silahkan ketikkan kata kunci pada menu search lalu akan muncul beberapa opsi, dan pilih sesuai dengan yang di maksud (Gambar 4)

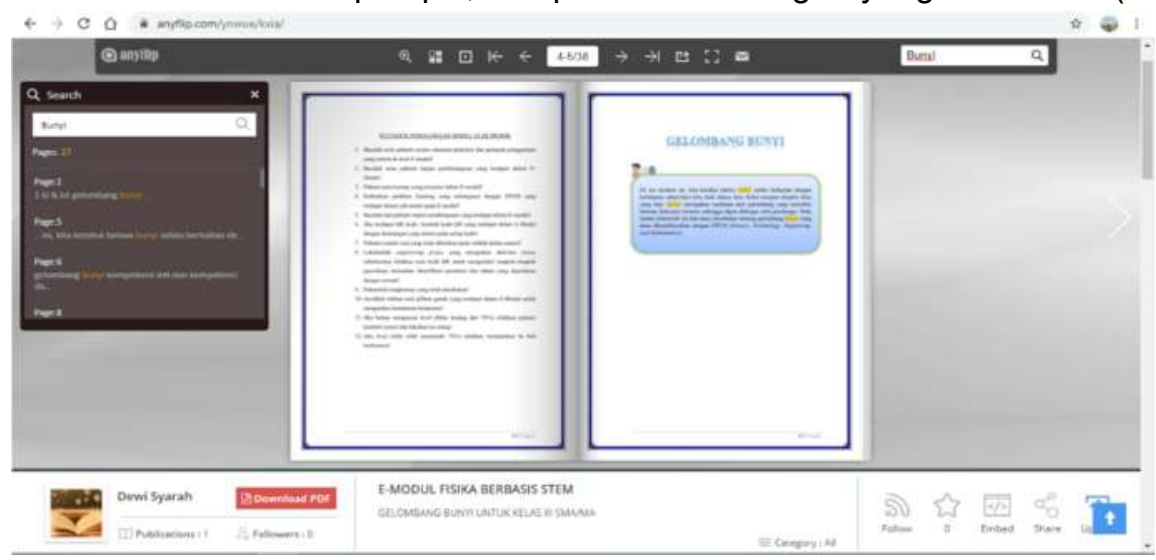

Gambar 4. Pencarian Kata Kunci

7. Jika ingin memperbesar tampilan silahkan klik tanda (+) yang terdapat pada menu di layar EModul (Gambar 5)

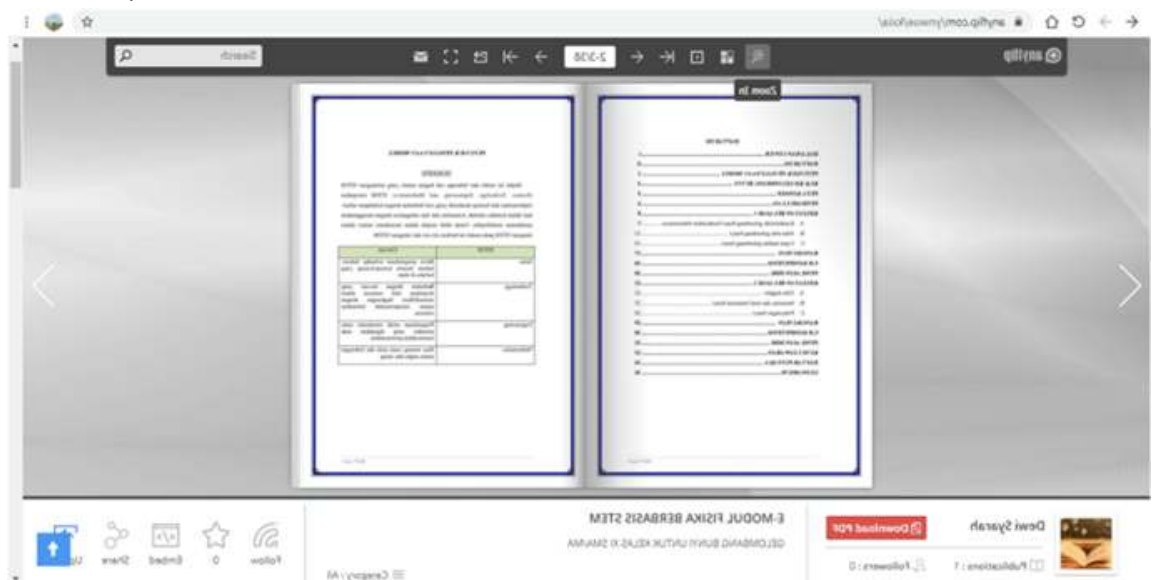

Gambar 5. Penyesuaian Tampilan 
Pengembangan E-Modul Fisika...

\section{PEMBAHASAN}

Penelitian ini mengembangkan sebuah bahan ajar jenis modul elektronik. Sebelum digunakan EModul ini harus melalui tahap validasi terlebih dahulu. Instrumen pengukuran atau validasi dalam EModul ini terdiri dari 19 indikator yang dibagi kedalam 4 aspek, yaitu kelayakan isi, kebahasaan, penyajian, dan kemandirian belajar. Aspek kelayakan isi terdiri dari 6 indikator, yaitu kesesuaian isi EModul dengan kompetensi inti dan kompetensi dasar, kesesuaian isi materi dengan tujuan pembelajaran yang ditetapkan, kesesuaian integrasi materi dengan STEM, kejelasan petunjuk penggunaan E-Modul, kebenaran materi dari aspek ilmu, kesesuaian isi soal dengan materi. Aspek kebahasaan terdiri dari 5 indikator, yaitu bahasa yang digunakan sesuai dengan kaidah Bahasa Indonesia, kalimat yang digunakan mudah dipahami, kejelasan dalam penulisan E-Modul, penggunaan bahasa secara efektif dan efisien, bahasa yang digunakan memiliki sifat komunikatif. Aspek penyajian terdiri dari 5 indikator, yaitu ditampilkan dalam bentuk menarik, kelengkapan informasi dan tujuan, mudah dipahami, memberi dorongan secara visual, jenis dan ukuran font sesuai. Aspek kemandirian belajar terdapat 3 indikator, yaitu mendorong rasa ingin tahu siswa, mendorong siswa untuk berinteraksi dengan sumber belajar, dan mendorong siswa untuk belajar secara mandiri dan tidak bergantung pada satu pihak saja.

E-Modul fisika berbasis Science, Technology, Engineering, and Mathematics (STEM) pada materi Bunyi ini divalidasi oleh 2 validator ahli dan 1 validator pengguna. Validator ahli merupakan ahli dalam biidang STEM dan ahli dalam bidang keilmuan fisika dan validator pengguna merupakan praktisi pengajar fisika di salah satu sekolah menengah atas di wilayah jember Skor yang diberikan disajikan pada tabel 2 berikut.

Tabel 2 Hasil validasi E-Modul fisika berbasis STEM

\begin{tabular}{cllll} 
No. & \multicolumn{1}{c}{ Aspek } & \multicolumn{1}{c}{ Skor } & Rata-rata & Tingkat validasi \\
\hline 1 & Aspek kelayakan isi & 3,61 & & \\
\cline { 1 - 3 } 2 & Aspek kebahasaan & 3,6 & \multirow{2}{*}{3,54} & Valid \\
\hline 3 & Aspek penyajian & 3,53 & & \\
\cline { 1 - 3 } 4 & Aspek kemandirian belajar & 3,44 & & \\
\hline
\end{tabular}

Berpedoman pada tabel 2 diperoleh bahwa tingkat validitas E-Modul berbasis STEM adalah valid yang berati modul tersebut layak untuk digunakan. Aspek kelayakan isi digunakan untuk melihat kesesuaian isi E-Modul dengan kompetensi inti dan kompetensi dasar, kesesuaian isi materi dengan tujuan pembelajaran, kesesuaian integrasi materi dengan Science, Technology, Engineering, and Mathematics (STEM), kejelasan petunjuk penggunaan modul, kebenaran materi dari aspek ilmu, dan kesuaian isi soal dengan materi. Pada aspek kelayakan isi memperoleh skor dari rentang 3,33 sampai dengan 4, dimana pada indikator kesesuaian integrasi materi dengan STEM dan kejelasan petunjuk penggunaan modul mendapat skor paling rendah yaitu 3,33 sedangkan pada indikator kesesuaian isi materi dengan tujuan pembelajaran yang telah ditetapkan mendapatkan skor tertinggi yaitu 4 . Sehingga hasil validasi pada aspek kelayakan isi me,peroleh skor rata-rata keseluruhan indikator yaitu 3,61 dengan presentase kevalidan $90,2 \%$.

Aspek kebahasaan digunakan untuk mengetahui kesesuaian bahasa yang digunakan dengan KBBI, kemudian kejelasan dan penggunaan bahasa sudah secara efektif dan efisien sehingga dapat mempermudah siswa untuk memahami materi. Aspek kebahasaan ini memiliki rentang nilai 3,33 sampai 4, dimana pada indikator bahasa yang digunakan sesuai dengan kaidah Bahasa Indonesia memiliki skor paling tinggi yaitu 4 . Sedangkan pada kejelasan dan penggunaan bahasa yang bersifat komunikatif memiliki skor paling rendah yaitu 3,33. Aspek kebahasaan ini memiliki rentang nilai 3,33 sampai 4, dimana pada indikator bahasa yang digunakan sesuai dengan kaidah Bahasa Indonesia memiliki skor paling tinggi yaitu 4. Sedangkan pada kejelasan dan penggunaan bahasa yang bersifat komunikatif memiliki skor paling rendah yaitu 3,33 . Secara keseluruhan rata-rata aspek kebahasaan memiliki skor 3,6 dengan prosentase sebesar $90 \%$.

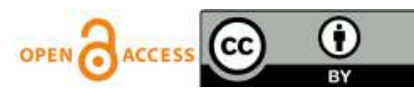


Pengembangan E-Modul Fisika...

Aspek penyajian memiliki tujuan untuk mengetahui kemenarikan E-Modul sebagai dorongan secara visual bagi siswa selama proses pembelajaran. Aspek penyajian ini memiliki rentang nilai antara 3,33 sampai 3,67. Beberapa indikator memiliki rata-rata nilai yang sama, seperti pada indikator E-Modul mudah dipahami dan memberi dorongan secara visual mendapatkan rata-rata paling rendah yaitu 3,33 dan pada indikator ditampilkan dalam bentuk yang menarik, kelengkapan informasi dan tujuan serta jenis dan ukuran font yang sesuai memiliki skor paling tinggi yaitu 3,67. Rata-rata aspek penyajian memiliki skor 3,53 dengan presentase sebesar $88,3 \%$.

Aspek kemandirian belajar bertujuan untuk mengetahui kemandirian siswa dalam belajar dengan menggunakan E-Modul berbasis STEM. Aspek kemandirian belajar ini memiliki tiga indikator. Indikator pertama mendorong rasa ingin tahu siswa yang memiliki rata-rata skor 3,33 . Indikator kedua mendorong siswa untuk berinteraksi dengan sumber belajar dengan rata-rata 3,67, indikator ini memiliki rata-rata skor paling tinggi diantara yang lainnya pada aspek kemandirian belajar. Indikator terakhir yaitu mendorong siswa untuk belajar secara mandiri dan tidak bergantung pada satu pihak saja mendapatkan skor rata-rata 3,33 . Sehingga rata-rata keseluruhan pada aspek kemandirian belajar adalah 3,44 dengan prosentase sebesar $86,1 \%$.

Hasil validasi oleh validator ahli pertama mendapatkan nilai prosentase sebesar $98,6 \%$, serta hasil validasi ahli kedua mendapatkan nilai prosentase sebesar $81,5 \%$, dan hasil validasi pengguna mendapatkan nilai prosentase sebesar $86,8 \%$. Skor tertinggi validasi diperoleh dari validator ahli pertama sebesar $98,6 \%$ sedangkan skor terendah didapatkan dari validator ahli kedua sebesar $81,5 \%$. Rata-rata hasil validasi oleh tiga validator, nilai tertinggi yaitu pada aspek kelayakan isi dengan skor 3,61 dan dengan nilai prosentase sebesar $90,2 \%$ sedangkan hasil validasi terendah yaitu pada aspek kemandirian belajar dengan rata-rata skor 3,44 dan dengan nilai prosentase sebesar $86,1 \%$. Total nilai akhir tiga validator pada keseluruhan aspek mendapatkan skor 3,54 dengan prosentase nilai sebesar $89 \%$. Berdasarkan tabel 3.3 E-modul fisika berbasis STEM pada materi bunyi dinyatakan valid dan layak digunakan dengan prosentase kevalidan yang sangat tinggi.

\section{PENUTUP}

E-Modul fisika berbasis STEM dinyatakan valid dan layak digunakan dengan skor 3,54 dan prosentase sebesar $89 \%$ dengan kriteria sangat tinggi sehingga dapat diimplementasikan ke sekolahsekolah dan digunakan sebagai bahan ajar siswa. Kelebihan dari E-Modul fisika berbasis STEM ini yaitu dapat memberikan solusi dari permasalahan yang terdapat dalam kehidupan sehari-hari karena materi dalam E-Modul diintegrasikan dengan empat bidang STEM. Selain itu E-Modul ini dapat diakses secara online maupun offline melalui smartphone/PC.

\section{DAFTAR PUSTAKA}

Adam, P., Saidi, L. O., \& Yahya, I. (2020). Peningkatan Kompetensi Guru-Guru SMA / SMK di Kota Kendari Melalui Pembuatan Media Pembelajaran Web Blog dan e-Modul Untuk Mendukung Pembelajaran Online. 2(2), 196-204.

Akaygun, S., \& Aslan-Tutak, F. (2016). STEM Images Revealing STEM Conceptions of Pre-Service Chemistry and Mathematics Teachers. International Journal of Education in Mathematics, Science and Technology, 4(1), 56. https://doi.org/10.18404/ijemst.44833

Akbar, S. (2013). Instrumen Perangkat Pembelajaran. PT. Remaja Rosdakarya.

Astiti, K. A. (2019). Pengembangan Bahan Ajar Fisika SMA Berbasis Kontekstual Pada Materi Suhu dan Kalor. Jurnal Pembelajaran Sains, 3(2), 29-34. 
Pengembangan E-Modul Fisika...

Depdiknas. (2017). Panduan praktis penyusunan E-Modul: Dirjen Dikdasmen Direktorat Pembinaan SMA.

Hartini, S., Mariani, I., Misbah, \& Sulaeman, N. F. (2020). Developing of students worksheets through STEM approach to train critical thinking skills. Journal of Physics: Conference Series, 1567(4). https://doi.org/10.1088/1742-6596/1567/4/042029

Herliandry, L. D., Nurhasanah, N., Suban, M. E., \& Kuswanto, H. (2020). Pembelajaran Pada Masa Pandemi Covid-19. JTP - Jurnal Teknologi Pendidikan, 22(1), 65-70. https://doi.org/10.21009/jtp.v22i1.15286

Latip, A. (2020). Minat Belajar Peserta Didik SMP Pada Pembelajaran STEM dengan Media Robot Edukasi. Jurnal Literasi Pendidikan Fisika, 1(02), 90-96. https://doi.org/10.30872/jlpf.v1i2.353

Muhammad, Y. (2018). Media dan Teknologi Pembelajaran. Prenada Media Grup.

Shernoff, D. J., Sinha, S., Bressler, D. M., \& Ginsburg, L. (2017). Assessing teacher education and professional development needs for the implementation of integrated approaches to STEM education. International Journal of STEM Education, 4(1), 1-16. https://doi.org/10.1186/s40594017-0068-1

Solviana, M. D. (2020). Pemanfaatan Teknologi Pendidikan di Masa Pandemi Covid-19: Penggunaan Fitur Gamifikasi Daring di Universitas Muhammadiyah Pringsewu Lampung. Al-Jahiz: Journal of Biology Education Research, 1(1), 1-14.

Sulaeman, N. F., Putra, P. D. ., Mineta, I., Hakamada, H., Takahashi, M., Ide, Y., \& Kumano, Y. (2020). Engaging STEM Education for High School Student in Japan: Exploration of Perception to Engineer Profession. Jurnal Penelitian Dan Pembelajaran IPA, 6(2), 189-205. https://doi.org/10.30870/jppi.v6i2.8449 